\title{
Self-stabilized, hydrophobic or PEGylated paclitaxel polymer prodrug nanoparticles for cancer therapy
}

\author{
Yinyin Bao, Elise Guégain, Julie Mougin, Julien Nicolas* \\ Institut Galien Paris-Sud, CNRS UMR 8612, Univ Paris-Sud, Faculté de Pharmacie, 5 rue \\ Jean-Baptiste Clément, 92290 Châtenay-Malabry, France.
}

*To whom correspondence should be addressed.

Email: julien.nicolas@u-psud.fr

Tel.: +33146835853 


\begin{abstract}
Facile derivatization of paclitaxel (Ptx) and subsequent "drug-initiated" synthesis of welldefined Ptx-polymer prodrugs was performed from nitroxide-mediated polymerization or reversible addition-fragmentation chain transfer polymerization. Short polyisoprene $\left(M_{\mathrm{n}}=\right.$ 2640-4310 g.mol $\left.{ }^{-1}, Ð \sim 1.1\right)$ or poly[oligo(ethylene glycol) methyl ether methacrylate)] $\left(M_{\mathrm{n}}=\right.$ 5580-7530 g.mol $\left.{ }^{-1}, Ð ~ 1.2\right)$ chains were grown from Ptx in a controlled fashion and enabled, for the first time, the formation of either self-stabilized, all-hydrophobic Ptx-polymer prodrug nanoparticles or their PEGylated counterparts. They exhibited average diameters in the 110 $235 \mathrm{~nm}$ range, great colloidal stability in PBS and cell culture medium, high drug loadings (up to $32 \mathrm{wt} . \%)$ and cytotoxicity similar to that of the parent drug on three different cancer cell lines (A549, L1210 and MCF-7). This versatile approach is expected to provide more potent anticancer nanocarriers and rejuvenate the development of Ptx-based nanomedicines.
\end{abstract}

\title{
Keywords
}

Polymer, prodrug, paclitaxel, nanoparticles, PEGylation, cancer 


\section{Introduction}

Paclitaxel (Ptx), a naturally occurring diterpene alkaloid, ${ }^{1}$ is one of the most potent chemotherapeutic agents used in the clinics for the treatment of a broad range of human solid tumors including breast, lung, ovarian, non-small cell, head and neck cancers. ${ }^{2-4}$ Despite the important therapeutic potential of Ptx, its use is limited by its poor water solubility $(<3$ $\left.\mu \mathrm{g} \cdot \mathrm{mL}^{-1}\right)^{5}$ and absence of ionizable groups to enable Ptx salt formation. Thus, Ptx is administered as an emulsion from a mixture with Cremophor EL (polyoxyl 35 castor oil) and dehydrated ethanol $(50 / 50, v / v)$, under the name of Taxol. ${ }^{6}$ However, Ptx formulations are incompatible with certain infusion sets and exhibit short-term colloidal stability, leading to precipitation. In addition, Cremophor EL is often associated with the occurrence of several side effects including hypersensitivity reactions, hematological toxicity, peripheral neurotoxicity and neuropathy. ${ }^{7-10}$

To overcome these limitations, nanoscale Ptx-loaded systems have been developed such as emulsions, liposomes, micelles, nanoparticles and dendrimers, but only a few of them have shown advanced clinical translation. ${ }^{11}$ For instance, Abraxane (albumin-bound Ptx nanoparticles), ${ }^{12}$ which was FDA-approved for the treatment of metastatic breast cancer, and Genexol-PM (Ptx-loaded polymer micelles), ${ }^{13}$ which is currently under phase II clinical trials, have both demonstrated reduced side effects. However, they did not exhibit any improvement in terms of pharmacokinetics (i.e., low plasma half-lives) because of rapid release of Ptx from the carrier, thus failing to deliver Ptx in a sustained manner. Conversely, Ptx-loaded PEGylated polypeptide micelles (NK105) showed reduced systemic neurotoxicity, greater plasma concentration and enhanced therapeutic efficacy compared to free Ptx during Phase I/II clinical trials. ${ }^{14}$ Nevertheless, the primary endpoint of a phase III related to progressionfree survival did not meet the expected statistical criteria.

To solve these issues, polymer prodrugs consisting in the covalent linkage of Ptx to 
polymers, have been developed. ${ }^{15}$ Polymer prodrugs indeed exhibit numerous advantages over traditional drug-loaded nanocarrier including absence of "burst release" (that is, the quick release post-administration of a significant fraction of the drug only adsorbed at the surface of the nanoparticles), enhanced drug loadings and drug solubility improvement. ${ }^{16}$ The most extensively used strategy to produce Ptx-polymer prodrugs consists in the linkage of Ptx by post-functionalization to preformed polymers ("grafting to" method), such as polyethylene glycol (PEG), ${ }^{17}$ poly(L-glutamic acid) (PGA), ${ }^{18}$ polylactide (PLA), ${ }^{19,20}$ dendrimer, ${ }^{21,22}$ and other block polymers. ${ }^{23-25}$ However, moderate conjugation efficacies, tedious multistep synthetic pathways and difficulty to accurately position the drug on the polymer chain were often witnessed. The polymerization of Ptx-conjugated monomers ("grafting through" method) was also investigated, but to a lesser extent. ${ }^{26,27}$

By analogy with polymer synthesis, the "grafting from" approach (also called "druginitiated"), which consists in the controlled growth of polymer chain from a drug, met with remarkable success for the design of various prodrug nanocarriers. ${ }^{28}$ Conversely to the previously-described approaches, drug-initiated polymer prodrugs exhibit several cuttingedge advantages: (i) they are easy to synthesize (only a few synthetic steps are required); (ii) they have a simple, well-defined structure with one drug attached at the extremity of each polymer chain; (iii) high drug loading can be achieved by targeting short polymer chain; (iv) this strategy can be applied to different drugs, thus conferring an important versatility in terms of the targeted pathology and (v) different polymers can be grown from the drug, which allow tuning of the solubility of the resulting materials; from water-soluble prodrugs to selfassembled nanostructures. The robustness of the drug-initiated method has been illustrated by its application to a variety of different polymer prodrugs constructed by either ring-opening polymerization $(\mathrm{ROP})^{29-32}$ or reversible-deactivation radical polymerization (RDRP), including nitroxide-mediated radical polymerization (NMP) or reversible addition- 
fragmentation chain transfer (RAFT) polymerization. ${ }^{33-40}$ Promising in vitro and in vivo results in the field of cancer therapy have been reported over the past few years. However, two major concerns currently restricting the wide applicability of this approach still remain: (i) all hydrophobic drug-polymer nanocarriers (i.e., where both the drug, such as Ptx, and the polymer are hydrophobic) exhibit poor colloidal stability, thus requiring post-stabilization by means of macromolecular surfactants and (ii) direct synthesis of PEGylated prodrugs which would open the door to long-circulating (stealth) Ptx-based conjugates, has never been reported. Whereas PEGylated prodrugs is of immediate interest to obtain high and rather constant systemic concentrations after administration to target tumors by the EPR effect, ${ }^{41}$ stable nanocarriers made of all-hydrophobic polymer prodrugs could advantageously be used to allow more flexibility in terms of the nature of the polymer and the drug used. Also, having different nanocarriers' surface properties could be crucial regarding their interaction with the biological medium and their fate in vivo. ${ }^{42}$

Herein, we tackle these issues and report on a global approach based on the facile derivatization of Ptx followed by subsequent "drug-initiated" RDRP to design surfactant-free, Ptx-polymer prodrug nanocarriers with opposite surface properties - either hydrophobic or PEGylated (Scheme 1), high drug loadings, great colloidal stability in biological media and anticancer activity similar to that of the parent drug on three different cancer cell lines. This versatile approach is expected to provide more potent nanocarriers for cancer therapy and rejuvenate the development of Ptx-based nanomedicines. 


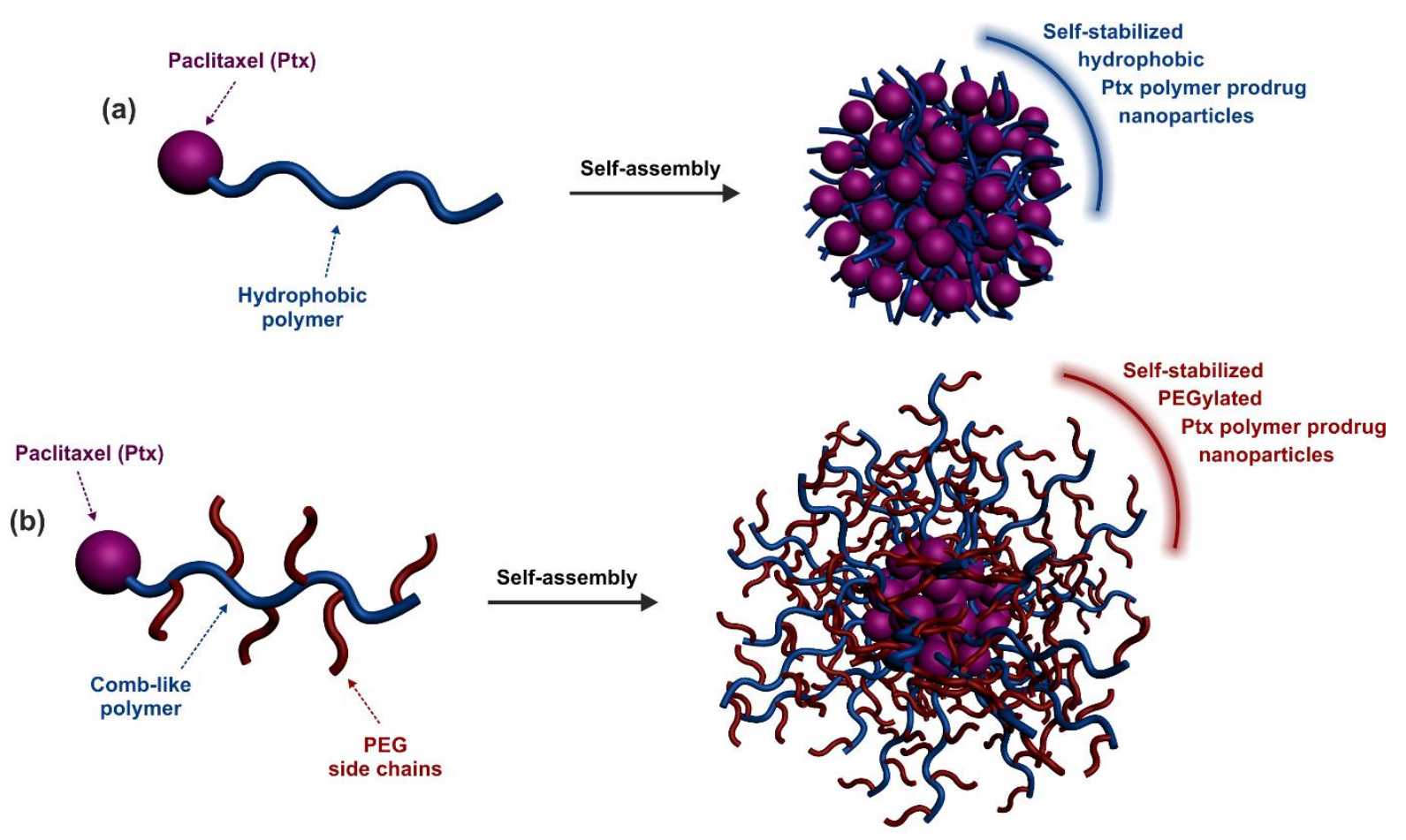

Scheme 1. Design of self-stabilized (a) hydrophobic and (b) PEGylated paclitaxel (Ptx) polymer prodrug nanoparticles by the drug-initiated method.

\section{Experimental Section}

\section{Materials}

Paclitaxel (Ptx) was purchased from Sequoia Research Products Limited (UK). N-tert-Butyl$N$-[1-diethylphosphono-(2,2-dimethylpropyl)] nitroxide (SG1, 85\%) was obtained from Arkema (France). Diglycolic anhydride and tetrabutylammonium fluoride were purchased

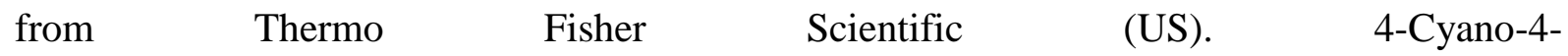
[(dodecylsulfanylthiocarbonyl)sulfanyl]pentanol (CDP) and oligo(ethylene glycol) methyl ether methacrylate $\left(M_{\mathrm{n}}=300 \mathrm{~g} \cdot \mathrm{mol}^{-1}\right.$, OEGMA) were purchased from Sigma-Aldrich. 2-[Ntert-Butyl- $N$-(1-diethoxyphosphoryl-2,2-di-methylpropyl)aminoxy] propionic acid (AMASG1), ${ }^{43}$ digly-AMA-SG1 and digly-PI were prepared according to published methods. ${ }^{36}$ LysoTracker Red was purchased from Life Technologies. DMEM and fetal bovine serum (FBS) were purchased from Dulbecco (Invitrogen, France). Penicillin was purchased from 
Lonza (Verviers, Belgium). All other materials were purchased from Aldrich at the highest available purity and used as received.

\section{Analytical methods}

Nuclear Magnetic Resonance Spectroscopy (NMR). NMR spectroscopy was performed in $5 \mathrm{~mm}$ diameter tubes in $\mathrm{CDCl}_{3}$ or DMSO- $d_{6}$ at $25{ }^{\circ} \mathrm{C} .{ }^{1} \mathrm{H}$ and ${ }^{13} \mathrm{C}$ NMR spectroscopy was performed on a Bruker Avance 300 spectrometer at $300 \mathrm{MHz}\left({ }^{1} \mathrm{H}\right)$ or $75 \mathrm{MHz}\left({ }^{13} \mathrm{C}\right)$. The chemical shift scale was calibrated on the basis of the internal solvent signals.

Mass spectra. Mass spectra were recorded with a Bruker Esquire-LC instrument. Highresolution (HR) mass spectra (electron spin ionization, ESI) were recorded on an ESI/TOF (LCT, Waters) LC-spectrometer.

Size Exclusion Chromatography (SEC). SEC was performed at $30{ }^{\circ} \mathrm{C}$ with two columns from Polymer Laboratories (PL-gel MIXED-D; $300 \times 7.5 \mathrm{~mm}$; bead diameter $5 \mathrm{~mm}$; linear part 400 to $4 \times 10^{5}$ g.mol ${ }^{-1}$ ) and a differential refractive index detector (SpectraSystem RI-150 from Thermo Electron Corp.). The eluent was chloroform at a flow rate of $1 \mathrm{~mL} \cdot \mathrm{min}^{-1}$ and toluene was used as a flow-rate marker. This technique allowed $M_{\mathrm{n}}$ (the number-average molar mass), $M_{\mathrm{w}}$ (the weight-average molar mass), and $M_{\mathrm{w}} / M_{\mathrm{n}}$ (the dispersity, $Ð$ ) to be determined. The calibration curve for Ptx-digly-PI was based on polystyrene (PS) standards (peak molar masses, $M_{\mathrm{p}}=162-523000 \mathrm{~g} \cdot \mathrm{mol}^{-1}$ ) from Polymer Laboratories. A polyisoprene (PI) calibration curve was then constructed by converting the PS standard peak molecular weights, $M_{\mathrm{PS}}$, to PI molecular weights, $\mathrm{M}_{\mathrm{PI}}$, using Mark- Houwink-Sakurada (MHS) constants determined for both polymers in $\mathrm{CCl}_{4}$ at $25{ }^{\circ} \mathrm{C}$. For PI, the MHS constants used were $K_{\mathrm{PI}}=$ $2.44 \times 10^{4}$ and $\alpha_{\mathrm{PI}}=0.712$. For PS, $K_{\mathrm{PS}}=7.1 \times 10^{4}$ and $\alpha_{\mathrm{PS}}=0.54\left(M_{\mathrm{W}}<16700{\mathrm{~g} . \mathrm{mol}^{-1}}^{-1}\right)$ or $K_{\mathrm{PS}}=1.44 \times 10^{4}$ and $\alpha_{\mathrm{PS}}=0.713\left(M_{\mathrm{W}}>16700{\left.\mathrm{~g} \cdot \mathrm{mol}^{-1}\right) .}^{44}\right.$ The calibration curve for Ptx-digly- 
POEGMA was based on poly(methyl methacrylate) (PMMA) standards (peak molar masses, $M_{\mathrm{p}}=625-625500 \mathrm{~g} \cdot \mathrm{mol}^{-1}$ ) from Polymer Laboratories.

Dynamic Light Scattering (DLS) and Zeta Potential. Nanoparticle diameters (Dz) and zeta potentials $(\zeta)$ were measured by dynamic light scattering (DLS) with a Nano ZS from Malvern (173 ${ }^{\circ}$ scattering angle) at a temperature of $25{ }^{\circ} \mathrm{C}$. The surface charge of the nanoparticles was investigated by $\zeta$-potential $(\mathrm{mV})$ measurement at $25{ }^{\circ} \mathrm{C}$ after dilution with 1 $\mathrm{mM} \mathrm{NaCl}$, using the Smoluchowski equation.

Cryogenic Transmission electron microscopy (Cryo-TEM). The morphology of the different nanoparticles was examined by Cryo-TEM. Briefly, $5 \mu \mathrm{L}$ of the nanoparticle suspension (5 mg.mL ${ }^{-1}$ ) was deposited on a Lacey Formvar/carbon 300 mesh copper microscopy grid (Ted Pella). Most of the drop was removed with a blotting filter paper and the residual thin film remaining within the holes was vitrified by plunging into liquid ethane. Samples were then observed using a JEOL 2100HC microscope.

Fluorescence spectroscopy. Emission spectra were obtained using a LS 50B fluorescence spectrometer from Perkin Elmer. All measurements were conducted at room temperature ( 25 ${ }^{\circ} \mathrm{C}$ ) with a spectral bandwidth (ex, em) of $2.5 \mathrm{~nm}$ and $\lambda_{\mathrm{ex}}=422 \mathrm{~nm}$.

\section{Synthesis methods}

Synthesis of Ptx-digly-AMA. Digly-AMA-SG1 (0.20 g, 0.39 mmol), DMAP (0.07 g, 0.6 mmol), and $\mathrm{EDC} . \mathrm{HCl}(0.11 \mathrm{~g}, 0.6 \mathrm{mmol})$ were dissolved in $5 \mathrm{~mL}$ anhydrous $\mathrm{CH}_{2} \mathrm{Cl}_{2}$ and mixed in a reaction flask under argon at room temperature. After $15 \mathrm{~min}$, a solution of paclitaxel $(0.25 \mathrm{~g}, 0.3 \mathrm{mmol})$ in DMF $(1 \mathrm{~mL})$ was added into the flask dropwise. After stirring at $30{ }^{\circ} \mathrm{C}$ for $22 \mathrm{~h}$, the mixture was poured into $30 \mathrm{~mL}$ of EtOAc. The organic phase was washed with brine before being dried over $\mathrm{MgSO}_{4}$. The residue was concentrated under 
reduced pressure and purified by flash chromatography $\left(\mathrm{SiO}_{2}\right.$, from $\mathrm{DCM} / \mathrm{EtOAc}=2 / 1$ to DCM/EtOAc $=1 / 1, \mathrm{v} / \mathrm{v})$ to give $0.32 \mathrm{~g}$ Ptx-digly-AMA as a white solid. Yield $=82 \% .{ }^{1} \mathrm{H}$ NMR (300 MHz, $\left.\mathrm{CDCl}_{3}\right)$ of the major diastereomer was shown for clarity: $\delta=8.16(\mathrm{~d}, 2 \mathrm{H}, \mathrm{J}$ = 7.5 Hz), $7.76(\mathrm{~d}, 2 \mathrm{H}, \mathrm{J}=7.5 \mathrm{~Hz}), 7.34-7.63(\mathrm{~m}, 11 \mathrm{H}), 7.09(\mathrm{~d}, 1 \mathrm{H}, \mathrm{J}=9.0 \mathrm{~Hz}), 6.21-6.30$ $(\mathrm{m}, 2 \mathrm{H}), 6.05(\mathrm{~d}, 1 \mathrm{H}, \mathrm{J}=9.0 \mathrm{~Hz}), 5.70(\mathrm{~d}, 1 \mathrm{H}, \mathrm{J}=6.9 \mathrm{~Hz}), 5.59(\mathrm{t}, 1 \mathrm{H}, \mathrm{J}=2.7 \mathrm{~Hz}), 4.99(\mathrm{dd}$, $1 \mathrm{H}, \mathrm{J}=8.1 \mathrm{~Hz}, \mathrm{~J}=1.5 \mathrm{~Hz}), 4.66(\mathrm{dd}, 1 \mathrm{H}, \mathrm{J}=6.6 \mathrm{~Hz}, \mathrm{~J}=6.6 \mathrm{~Hz}), 3.88-4.44(\mathrm{~m}, 14 \mathrm{H}), 3.83(\mathrm{~d}$, $1 \mathrm{H}, \mathrm{J}=6.8 \mathrm{~Hz}), 3.38(\mathrm{~d}, 1 \mathrm{H}, \mathrm{J}=26.4 \mathrm{~Hz}), 2.36-2.61(\mathrm{~m}, 6 \mathrm{H}), 2.23(\mathrm{~s}, 3 \mathrm{H}), 2.14-2.19(\mathrm{~m}, 1 \mathrm{H})$, $1.94(\mathrm{~s}, 3 \mathrm{H}), 1.84-1.89(\mathrm{~m}, 1 \mathrm{H}), 1.80(\mathrm{~d}, 1 \mathrm{H}, \mathrm{J}=3.6 \mathrm{~Hz}), 1.68(\mathrm{~s}, 3 \mathrm{H}), 1.46(\mathrm{~d}, 3 \mathrm{H}, \mathrm{J}=6.9$ $\mathrm{Hz}), 1.22-1.30(\mathrm{~m}, 9 \mathrm{H}), 1.06-1.15(\mathrm{~m}, 24 \mathrm{H}) .{ }^{13} \mathrm{C} \mathrm{NMR}\left(75 \mathrm{MHz}, \mathrm{CDCl}_{3}\right)$ of the mixture of the diastereomers: $\delta=203.8,173.6,171.2,169.9,169.3,168.9,167.7,167.1$ (d), 167.0, 142.4, 136.8 (d), 133.5, 133.1, 132.1 (d), 130.3 (2C), 129.4, 129.2 (2C), 128.8 (2C), 128.7 (2C), $128.5,127.3,127.1,126.6$ (2C), 84.5, 82.2, 81.2, 79.1, 76.5, 75.5, 75.2, 74.5, 72.2 (d),70.54, 68.6, 68.0, 62.6 (d), 61.9 (d), 61.75, 59.0 (d), 58.6, 52.7, 45.6, 43.3 (d), 35.6, 29.6 (t), 27.9, 26.9, 22.8, 22.3, 22.1, 20.9, 19.3 (d), 16.5 (d), 16.3, 16.2, 14.8, 9.7. MS (ESI+): m/z = 1385.4 $(\mathrm{M}+\mathrm{Na})^{+}$

Polymerization of isoprene from Ptx-digly-AMA. Ptx-digly-AMA (55 mg, $0.04 \mathrm{mmol}$ ) was placed in a $15 \mathrm{~mL}$ capacity pressure tube (Ace Glass 8648-164) fitted with plunger valves and thermowells. Isoprene $(0.8 \mathrm{~mL}, 8.0 \mathrm{mmol})$ and dioxane $(0.8 \mathrm{~mL})$ were added and the tube was subjected to three cycles of freeze-thaw degassing, then backfilled with argon. The tube was placed in an oil bath at $115{ }^{\circ} \mathrm{C}$ for $4(\mathbf{P 1}), 8(\mathbf{P 2})$, or $16 \mathrm{~h}(\mathbf{P 3})$ and then cooled to room temperature by placing in a bath of cold water. The residue was concentrated under reduced pressure and precipitated in methanol to give Ptx-digly-PI as a colorless product. Another two polymerizations were performed for $16 \mathrm{~h}$ with $[\text { isoprene }]_{0} /[\mathrm{Ptx} \text {-digly-AMA }]_{0}=300 / 1(\mathbf{P 4})$ and 400/1 (P5). 
Synthesis of Digly-CDP. 4-Cyano-4-[(dodecylsulfanylthiocarbonyl)sulfanyl]pentanol (CDP) $(0.20 \mathrm{~g}, 0.5 \mathrm{mmol})$ was mixed with diglycolic anhydride $(0.15 \mathrm{~g}, 1.25 \mathrm{mmol})$ and triethylamine $(0.35 \mathrm{~mL}, 2.5 \mathrm{mmol})$ in anhydrous $\mathrm{CH}_{2} \mathrm{Cl}_{2}(4 \mathrm{~mL})$ and the reaction mixture was stirred at room temperature for $26 \mathrm{~h}$ under argon. The mixture was poured into $20 \mathrm{~mL}$ of $\mathrm{CH}_{2} \mathrm{Cl}_{2}$ and the organic phase was washed with $1 \mathrm{M} \mathrm{HCl}$ and brine before being dried over $\mathrm{MgSO}_{4}$. The residue was concentrated under reduced pressure to give $0.23 \mathrm{~g}$ of Digly-CDP as an orange liquid. Yield $=88 \% .{ }^{1} \mathrm{H}$ NMR $\left(300 \mathrm{MHz} \mathrm{CDCl}_{3}\right): \delta=4.24-4.27(\mathrm{~m}, 6 \mathrm{H}), 3.33(\mathrm{t}$, $2 \mathrm{H}, \mathrm{J}=7.5 \mathrm{~Hz}), 1.95-2.33(\mathrm{~m}, 4 \mathrm{H}), 1.87(\mathrm{~s}, 3 \mathrm{H}), 1.70(\mathrm{~m}, 2 \mathrm{H}), 1.26-1.40(\mathrm{~m}, 18 \mathrm{H}), 0.88(\mathrm{t}$, $3 \mathrm{H}, \mathrm{J}=6.6 \mathrm{~Hz}) .{ }^{13} \mathrm{C} \mathrm{NMR}\left(75 \mathrm{MHz}, \mathrm{CDCl}_{3}\right): \delta=217.2,171.4,170.4,119.2,69.0,68.8,64.3$, $45.6,37.1,35.5,31.9,29.6$ (2C), 29.5, 29.4, 29.3, 29.0, 28.9, 27.7, 24.9, 24.2, 22.7, 14.1. MS $(\mathrm{ESI}+): \mathrm{m} / \mathrm{z}=528.2(\mathrm{M}+\mathrm{Na})^{+}$.

Synthesis of Ptx-digly-CDP. Digly-CDP (0.45 g, 0.9 mmol), DMAP (0.12 g, $1.0 \mathrm{mmol})$, and EDC. $\mathrm{HCl}(0.2 \mathrm{~g}, 1.0 \mathrm{mmol})$ were dissolved in $5 \mathrm{~mL}$ anhydrous $\mathrm{CH}_{2} \mathrm{Cl}_{2}$ and mixed in a reaction flask under argon at room temperature. After $15 \mathrm{~min}$, a solution of paclitaxel $(0.30 \mathrm{~g}$, $0.35 \mathrm{mmol})$ in DMF $(1 \mathrm{~mL})$ was added into the flask dropwise. After being stirred at $30{ }^{\circ} \mathrm{C}$ for $26 \mathrm{~h}$, the mixture was poured into $50 \mathrm{~mL}$ of EtOAc. The organic phase was washed with $\mathrm{NaHCO}_{3}$ aqueous solution and brine before being dried over $\mathrm{MgSO}_{4}$. The residue was concentrated under reduced pressure and purified by flash chromatography $\left(\mathrm{SiO}_{2}\right.$, from $\mathrm{DCM} / \mathrm{EtOAc}=5 / 1$ to $\mathrm{DCM} / \mathrm{EtOAc}=1 / 1, \mathrm{v} / \mathrm{v})$ to give $0.20 \mathrm{~g}$ Ptx-digly-CDP as a yellow sticky solid. Yield $=43 \% .{ }^{1} \mathrm{H}$ NMR $\left(300 \mathrm{MHz}, \mathrm{CDCl}_{3}\right): \delta=8.17(\mathrm{~d}, 2 \mathrm{H}, \mathrm{J}=7.2 \mathrm{~Hz}), 7.77(\mathrm{~d}$, $2 \mathrm{H}, \mathrm{J}=7.5 \mathrm{~Hz}), 7.35-7.61(\mathrm{~m}, 11 \mathrm{H}), 7.09(\mathrm{~d}, 1 \mathrm{H}, \mathrm{J}=8.7 \mathrm{~Hz}), 6.18-6.29(\mathrm{~m}, 2 \mathrm{H}), 6.05(\mathrm{~d}, 1 \mathrm{H}$, $\mathrm{J}=9.0 \mathrm{~Hz}), 5.70(\mathrm{~d}, 1 \mathrm{H}, \mathrm{J}=6.9 \mathrm{~Hz}), 5.59(\mathrm{~m}, 1 \mathrm{H}), 4.99(\mathrm{dd}, 1 \mathrm{H}, \mathrm{J}=7.8 \mathrm{~Hz}, \mathrm{~J}=1.8 \mathrm{~Hz})$, 4.11-4.48 (m, 9H), $3.83(\mathrm{~d}, 1 \mathrm{H}, \mathrm{J}=6.3 \mathrm{~Hz}), 3.31(\mathrm{t}, 2 \mathrm{H}, \mathrm{J}=6.6 \mathrm{~Hz}), 2.48(\mathrm{~s}, 3 \mathrm{H}), 2.35-2.61$ (m, 3H), 2.23 (s, 3H), 2.14-2.25 (m, 3H), 1.94 (s, 3H), 1.85 (s. 3H), 1.80-2.01 (m, 2H), 1.68 $(\mathrm{s}, 3 \mathrm{H}), 1.65(\mathrm{~m}, 2 \mathrm{H}), 1.14-1.39(\mathrm{~m}, 27 \mathrm{H}), 0.88(\mathrm{t}, 3 \mathrm{H}, \mathrm{J}=6.3 \mathrm{~Hz}) .{ }^{13} \mathrm{C} \mathrm{NMR}(75 \mathrm{MHz}$, 
$\left.\mathrm{CDCl}_{3}\right): \delta=203.8,171.2,169.8,169.0,167.7,167.1,167.0,162.5,142.5,136.8,133.6(2 \mathrm{C})$ 132.9,131.9, 130.2 (2C), 129.3, 129.1 (2C), 128.7 (2C), 128.6 (2C), 127.3 (2C), $126.6(2 \mathrm{C})$, $119.3,84.5,81.1,79.1,76.5,75.6,75.2,74.5,72.1(\mathrm{~d}), 68.1,68.0,63.8,58.5,52.8,46.7,45.6$, $43.2,37.1,36.5,35.6,31.9,31.4,29.6$ (2C), 29.5, 29.4, 29.3, 29.1, 28.9, 27.7, 26.8, 25.0, 24.9, 24.8, 24.2, 22.8, 22.7, 22.2, 20.8, 14.8, 14.1, 9.6. MS (ESI+): $\mathrm{m} / \mathrm{z}=1363.3(\mathrm{M}+\mathrm{Na})^{+}$.

Polymerization of OEGMA from Ptx-digly-CDP. Ptx-digly-CDP (53.6 mg, $0.04 \mathrm{mmol}$ ), AIBN (0.7 mg, $0.004 \mathrm{mmol})$, OEGMA (0.24 g, $0.80 \mathrm{mmol})$ and DMF (1.2 mL) were placed into a glass vial and the resulting solution was purged with argon for $30 \mathrm{~min}$. The tube was placed in an oil bath at $70{ }^{\circ} \mathrm{C}$ for $4 \mathrm{~h}$ and then cooled to room temperature by placing in a bath of cold water. The residue was concentrated under reduced pressure and precipitated in cyclohexane and ether to give Ptx-digly-POEGMA as a yellow viscous liquid (P6). Another polymerization was performed for $4 \mathrm{~h}$ with $[\mathrm{OEGMA}]_{0} /[\mathrm{Ptx}-\operatorname{digly}-\mathrm{CDP}]_{0}=30 / 1(\mathbf{P 7})$.

\section{Nanoparticle preparation}

Nanoparticles were prepared by the nanoprecipitation technique. Briefly, $1.0 \mathrm{mg}$ of the corresponding polymer was dissolved in $0.5 \mathrm{~mL}$ of THF, and added dropwise to $1 \mathrm{~mL}$ MilliQ water under stirring. THF was evaporated at ambient temperature using a rotary evaporator. Average diameter $\left(D_{\mathrm{z}}\right)$ and zeta potential measurements were carried out in triplicate.

\section{Critical aggregation concentration}

Solvent-assisted solubilization method was used to prepare the samples for fluorescence experiments (i.e., to uniformly distribute the $\mathrm{C} 153$ fluorescent dye in the micelle cores). ${ }^{45}$ THF was used because it is a good solvent for the polymer and for the dye. For P4 (Ptx-digly$\mathrm{PI})$, a set of solution was prepared with polymer concentrations varying from $0.0001 \mathrm{mg} . \mathrm{mL}^{-1}$ 
to $0.5 \mathrm{mg} . \mathrm{mL}^{-1}$ whereas for $\mathbf{P 6}$ and $\mathbf{P 7}$ (Ptx-digly-POEGMA), a set of solutions were prepared with polymer concentrations varying from $0.001 \mathrm{mg} \cdot \mathrm{mL}^{-1}$ to $2 \mathrm{mg} \cdot \mathrm{mL}^{-1}$. All solutions contained the same amount of $\mathrm{C} 153\left(3.10^{-2} \mathrm{mM}\right)$. First, concentrated solutions of polymer and C153 were prepared in THF. The appropriate volume of both polymer and C153 solutions was transferred into small vials and water was added dropwise under gentle stirring. The final solutions (always containing less than $10 \% \mathrm{v} / \mathrm{v}$ of THF) were equilibrated for at least $24 \mathrm{~h}$ at room temperature. Fluorescence spectra were recorded in $10 \mathrm{~mm}$ optical path length quartz cell. Maximum fluorescence intensities vs $\log$ (concentration) were plotted and CAC were graphically determined when the slope change.

\section{Drug release}

To determine the Ptx release kinetics from the polymer prodrug nanoparticles, $100 \mu \mathrm{L}$ of nanoparticles Ptx-digly-PI (4.0 mg.mL $\left.{ }^{-1}\right)$ or Ptx-digly-POEGMA $\left(2.0 \mathrm{mg} . \mathrm{mL}^{-1}\right)$ were added to $900 \mu \mathrm{L}$ of human serum or PBS solution. The mixture was incubated at $37{ }^{\circ} \mathrm{C}$, and aliquots $(100 \mu \mathrm{L})$ of incubation medium were removed at different time points, spiked with $4 \mu \mathrm{L}$ of $500 \mu \mathrm{M} \mathrm{N}$-octylbenzamide (Internal Standard) before addition of $1 \mathrm{~mL}$ of a mixture of acetonitrile/methanol (90/10, v/v) and ultracentrifugated (15000 G, $\left.20 \mathrm{~min}, 4{ }^{\circ} \mathrm{C}\right)$. Supernatant was then evaporated to dryness under a nitrogen flow at $30^{\circ} \mathrm{C}$. The released drug was quantified by reverse-phase HPLC (Waters, Milford, MA 01757, USA) with a C18 column. Briefly, the chromatographic system consisted of a Waters 1525 Binary LC pump, a Waters 2707 Autosampler, a C18 Uptisphere column $(3 \mu \mathrm{m}, 150 \times 4.6 \mathrm{~mm}$, Interchim), HPLC column temperature controllers (model 7950 column heater and chiller, Jones Chromatography, Lakewood, CO), and a Waters 2998 programmable photodiode-array detector. The HPLC column was maintained at $30{ }^{\circ} \mathrm{C}$. Detection was monitored at $227 \mathrm{~nm}$. The HPLC mobile phase was acetonitrile/water (70/30, v/v). The residues were dissolved in 
$100 \mu \mathrm{L}$ of mobile phase and elution was carried out at a flow rate of $1.0 \mathrm{~mL} / \mathrm{min}$ isocratically for $7 \mathrm{~min}$ with acetonitrile/water (70/30, v/v) followed by a 1 min linear gradient to $95 \%$ acetonitrile. This was followed by a 15 -min hold at $95 \%$ acetonitrile, and a 1 min linear gradient back to acetonitrile/water $(70 / 30, \mathrm{v} / \mathrm{v})$. The system was held for $6 \mathrm{~min}$ for equilibration back to initial conditions.

\section{Biological activity experiments}

Cell Lines and Cell Culture. Murine leukemia cell line L1210 was kindly provided by Dr. Lars Petter Jordheim (Université Claude Bernard Lyon I, Lyon, France), maintained as recommended. Lung carcinoma cell line A549, and breast adenocarcinoma cell line MCF-7 were obtained from the American Type Culture Collection and maintained as recommended. Briefly, all cells were cultured in Dulbecco's minimal essential medium (DMEM). All media were supplemented with $10 \%$ heat-inactivated $\mathrm{FBS}\left(56{ }^{\circ} \mathrm{C}, 30 \mathrm{~min}\right)$ and penicillin $(100$ U.mL ${ }^{-1}$ ). Cells were maintained in a humid atmosphere at $37{ }^{\circ} \mathrm{C}$ with $5 \% \mathrm{CO}_{2}$.

Cell imaging. A549 cells were cultured in a culture dish for $24 \mathrm{~h}$ to achieve confluence. Cells were then incubated with Ptx-digly-PI/Napht-PI or Ptx-digly-POEGMA/Napht-PI nanoparticles ( $1 \mathrm{wt} . \%$ of dye content), at a concentration of $10 \mu \mathrm{g} \cdot \mathrm{mL}^{-1}$ at $37{ }^{\circ} \mathrm{C}$ for $20 \mathrm{~h}$, then incubated with LysoTracker Red for 30 min and Hoechst 33342 for 20 min under same conditions. After treatment, the cells were washed with Dulbecco's phosphate buffered saline (PBS) and imaged using a confocal microscope (Zeiss) with a $\times 60$ oil-immersion objective. The excitation wavelength was $405 \mathrm{~nm}$ and $543 \mathrm{~nm}$, and the fluorescence was collected in the range of 410-440 m, 450-560 nm, and 569-682 nm, respectively.

In vitro anticancer activity. The cytotoxicity of the different polymer prodrug nanoparticles and Ptx was investigated by MTT [3-(4,5-dimethylthiazol-2-yl)-2,5-diphenyl tetrazolium 
bromide] viability test on L1210, A549 and MCF-7 cell lines. Briefly, cells $\left(5 \times 10^{3} /\right.$ well) were seeded in 96-well plates for $24 \mathrm{~h}$ incubation (only $1 \mathrm{~h}$ of incubation for L1210 cells), then the cells were exposed to a series of concentrations of different polymer prodrug nanoparticles, control polymer nanoparticles, or free Ptx for $72 \mathrm{~h}$. After drug exposition, the medium was added with $20 \mu \mathrm{L}$ of MTT solution ( $5 \mathrm{mg} \cdot \mathrm{mL}^{-1}$ in PBS) for each well. The plates were incubated for $1 \mathrm{~h}$ at $37^{\circ} \mathrm{C}$ and the medium was removed (by centrifugation for L1210). $200 \mu \mathrm{L}$ of DMSO were then added to each well to dissolve the precipitates. Absorbance was measured at $570 \mathrm{~nm}$ using a plate reader (Metertech $\Sigma$ 960, Fisher Bioblock, Illkirch, France). The percentage of surviving cells was calculated as the absorbance ratio of treated to untreated cells. The inhibitory concentration $50 \%\left(\mathrm{IC}_{50}\right)$ of the treatments was determined from the dose-response curve. All experiments were set up in quadruplicate to determine means and SDs.

\section{Results and Discussion}

\section{Synthesis of Ptx-based polymer prodrugs}

Derivatization of Ptx was achieved by two different pathways; each of them using one particular RDRP technique. Not only it gives more flexibility in terms of macromolecular engineering and polymer prodrug synthesis, but it allows to take advantage of the different benefits of each polymerization method. Herein, it is applied to the synthesis of a Ptx-bearing alkoxyamine and a Ptx-bearing RAFT agent for conducting NMP or RAFT polymerization, respectively (Figure 1). These two RDRP methods were selected given their well-known advantages in terms of simplicity, innocuousness and robustness.

Derivatization of Ptx was selectively performed on its C-2'-hydroxyl group to preserved its bioacitivity. ${ }^{46}$ Esterification was achieved by EDC/DMAP-assisted coupling chemistry with an alkoxyamine initiator based on the nitroxide SG1 (AMA-SG1), ${ }^{43}$ and a 
chain

transfer

agent

(CTA)

based

on

4-cyano-4-

[(dodecylsulfanylthiocarbonyl)sulfanyl]pentanol (CDP). AMA-SG1 and CDP were previously reacted with diglycolic anhydride, giving digly-AMA-SG1 and digly-CDP (Figure 1), to position a diglycolate linker in between the drug and the RDRP moiety to promote drug release. ${ }^{36}$ When compared to a single ester bond, the diglycolate group has indeed been shown to endow the drug-polymer conjugates with greater drug release kinetics, resulting in an enhanced therapeutic effect. The resulting Ptx-digly-AMA-SG1 and Ptx-digly-CDP (Figure 1) were obtained with $82 \%$ and $43 \%$ coupling yields, respectively (see experimental part, Figures S1 and S2).

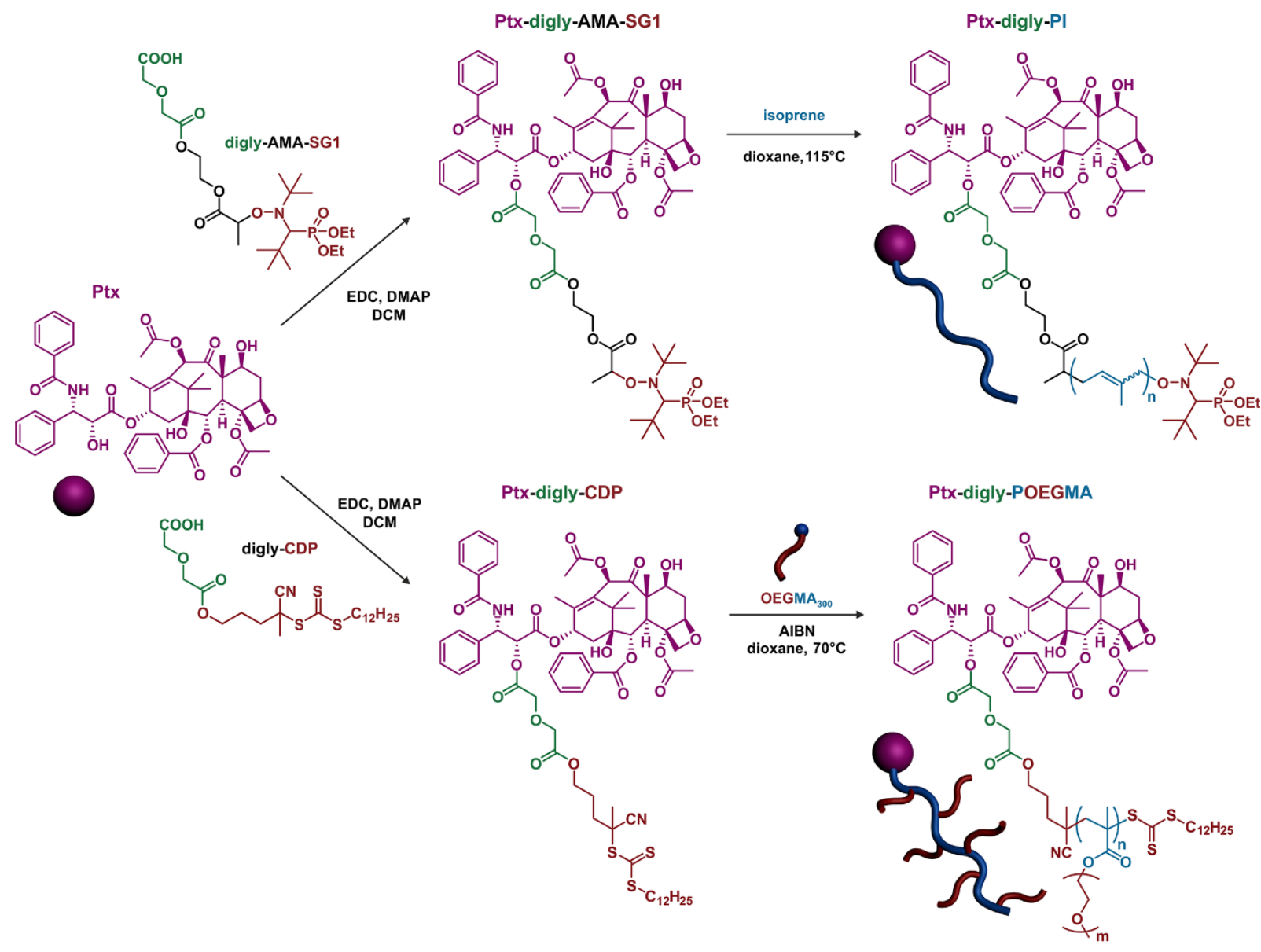

Figure 1. Synthesis of hydrophobic paclitaxel-diglycolate-polyisoprene (Ptx-digly-PI) and PEGylated paclitaxel-diglycolate-poly[oligo(ethylene glycol) methyl ether methacrylate) ${ }_{300}$ ] (Ptx-digly-POEGMA 300 ) prodrugs by nitroxide-mediated polymerization (NMP) and 
reversible addition-fragmentation chain transfer (RAFT) polymerization, respectively.

To obtain all-hydrophobic polymer prodrugs, the polymerization of isoprene was initiated by Ptx-digly-AMA-SG1 to grow short polyisoprene (PI) chains from Ptx and achieve welldefined Ptx-digly-PI prodrugs. PI was selected given its chemical ${ }^{23}$ and enzymatic ${ }^{47}$ degradability, as well as its biocompatibility, ${ }^{48}$ and its structural similarity with many biocompatible natural terpenoids (e.g., retinol, vitamin E). Also, NMP of isoprene is known to give well-controlled PI chains from a variety of different SG1-based functional alkoxyamines. ${ }^{44}$ A library of well-defined Ptx-digly-PI conjugates with variable chain length were successfully obtained by varying the polymerization time from 4 to $16 \mathrm{~h}$ and the [isoprene $]_{0} /[\text { Ptx-digly-AMA-SG1 }]_{0}$ ratio from 200/1 to 400/1 (see experimental part, Table 1, Figures S3 and S4). $M_{\mathrm{n}}$ of the purified Ptx-digly-PI prodrugs (Table 1) ranged from 2640 to 4310 g.mol ${ }^{-1}(\mathbf{P 1}-\mathbf{P 5})$ and had low dispersities $\left(~(=1.07-1.10)\right.$, as demonstrated by ${ }^{1} \mathrm{H}-\mathrm{NMR}$ spectroscopy and SEC. By tuning the PI chain length, the drug loading varied from $\sim 32$ to 20 wt.\%, which represents high values compared to traditional Ptx-loaded polymer nanoparticles where drug loadings usually reach just a few percent.

To obtain PEGylated Ptx-polymer prodrug nanocarriers without requiring poststabilization by PEG-based surfactants, Ptx-digly-CDP was used to perform the RAFT polymerization of oligo(ethylene glycol) methyl ether methacrylate $\left(M_{\mathrm{n}}=300 \mathrm{~g} \cdot \mathrm{mol}^{-1}\right.$, OEGMA $_{300}$ ). POEGMA derivatives have been extensively used as alternative to linear PEGs for protein bioconjugation or for the coating of nanoparticles owing to their favorable properties (e.g., water-solubility, biocompatibility, stealthiness, etc.). ${ }^{49}$ However, it has never been used to prepare PEGylated drug-initiated polymer prodrugs. The RAFT polymerization was conducted at two different $[\mathrm{OEGMA}]_{0} /[\mathrm{Ptx}-\text { digly-CDP }]_{0}$ ratios $(20: 1$ and 30:1), resulting in well-defined Ptx-digly-POEGMA conjugates P6 $\left(M_{\mathrm{n}, \mathrm{SEC}}=5580 \mathrm{~g} \cdot \mathrm{mol}^{-1}, \doteq=1.19\right)$ and $\mathbf{P 7}$ $\left(M_{\mathrm{n}, \mathrm{SEC}}=7530 \mathrm{~g} \cdot \mathrm{mol}^{-1}, Ð=1.26\right)$, respectively, as shown in Table 1 and in Figures S5-S6. 
Drug loadings were calculated to be 15.3 for $\mathbf{P 6}$ and 11.3 wt.\% for P7.

Table 1. Characterization of Ptx-digly-PI and Ptx-digly-POEGMA Polymer Prodrugs and Nanoparticles.

\begin{tabular}{|c|c|c|c|c|c|c|c|c|c|}
\hline Sample & Polymer & $\begin{array}{c}M_{\mathrm{n}, \mathrm{SEC}}{ }^{a} \\
\left(\text { g.mol }^{-1}\right)\end{array}$ & $D P_{\mathrm{n}, \mathrm{SEC}}{ }^{b}$ & $D P_{\mathrm{n}, \mathrm{NMR}}{ }^{c}$ & $\overline{\boldsymbol{D}^{a}}$ & $\begin{array}{c}D_{z}^{d} \\
(\mathbf{n m})\end{array}$ & $\mathbf{P S D}^{d}$ & $\begin{array}{c}\zeta^{e} \\
(\mathbf{m V})\end{array}$ & $\begin{array}{l}\text { \% Ptx } \\
\text { (wt.\%) }\end{array}$ \\
\hline $\mathbf{P 1}$ & PI & 2640 & 18 & 24 & 1.07 & 236 & 0.10 & -77 & 32.3 \\
\hline $\mathbf{P 2}$ & PI & 2670 & 19 & 24 & 1.08 & 217 & 0.09 & -76 & 32.0 \\
\hline P3 & PI & 2790 & 21 & 33 & 1.08 & 145 & 0.07 & -61 & 30.6 \\
\hline P4 & PI & 3560 & 32 & 42 & 1.08 & 133 & 0.18 & -63 & 24.0 \\
\hline P5 & PI & 4310 & 43 & 51 & 1.10 & 111 & 0.07 & -63 & 19.8 \\
\hline P6 & POEGMA & 5580 & 14 & 7 & 1.19 & 133 & 0.06 & -35 & 15.3 \\
\hline P7 & POEGMA & 7530 & 21 & 9 & 1.26 & 151 & 0.15 & -33 & 11.3 \\
\hline
\end{tabular}

${ }^{a}$ Determined by SEC, calibrated with PS standards and converted into PI by using Mark-Houwink-Sakurada parameters for Ptx-digly- $\mathrm{PI}^{44}$ and calibrated with PMMA standards for Ptx-digly-POEGMA. ${ }^{b}$ Calculated according to $D P_{\mathrm{n}, \mathrm{SEC}}=\left(M_{\mathrm{n}, \mathrm{SEC}}-\mathrm{MW}_{\text {alkoxyamine }}\right) / \mathrm{MW}_{\text {isoprene }}$ for Ptx-digly-PI and $\left(M_{\mathrm{n}, \mathrm{SEC}}-\mathrm{MW}_{\mathrm{CTA}}\right) / \mathrm{MW}_{\mathrm{OEGMA}}$ for Ptx-digly-POEGMA. ${ }^{c}$ Calculated from ratio of areas under the peak at 7.1-8.2 ppm (proton on the benzene of $\mathrm{Ptx}$ ) and 5.0-5.5 ppm (vinylic $\mathrm{H}$ in isoprene repeat unit (1,4-addition), corresponding to $\sim 81 \%$ of total isoprene units) for Ptx-digly-PI, ${ }^{44}$ and calculated from the ratio of areas under the peak at 7.1-8.2 ppm (proton on the benzene of Ptx) and 3.3-4.3 ppm (OEG protons) for Ptx-digly-POEGMA. ${ }^{d}$ Determined by DLS. ${ }^{e}$ Zeta potential. ${ }^{f} \% \mathrm{Ptx}=\mathrm{MW}_{\mathrm{Ptx}} / M_{\mathrm{n}, \mathrm{polymer}}$.

\section{Formulation into nanoparticles and physicochemical properties}

The critical aggregation concentrations (CAC) of Ptx-digly-PI and Ptx-digly-POEGMA prodrugs in water were first determined to evaluate their ability to self-assemble into nanoparticles. Measurements were performed by means of fluorescence spectroscopy by using coumarin 153 (C153), which is an appropriate dye to study self-assembly in water. ${ }^{45}$ Ptx-digly-PI led to CAC = $3.9 \mu \mathrm{g} \cdot \mathrm{mL}^{-1}$ for $\mathbf{P 4}$ (Figure 2a) whereas PEGylated Ptx-diglyPOEGMA led to CAC $=77.6$ and $21.4 \mu \mathrm{g} \cdot \mathrm{mL}^{-1}$ for $\mathbf{P 6}$ and $\mathbf{P 7}$, respectively (Figure 2b). As expected because of their hydrophobic nature, Ptx-digly-PI prodrugs exhibited a much lower CAC than those of Ptx-digly-POEGMA. These values are nevertheless small enough to allow formation of nanoparticles at concentrations usually employed from drug delivery purposes (ca. mg.mL $L^{-1}$ ). 
(a)

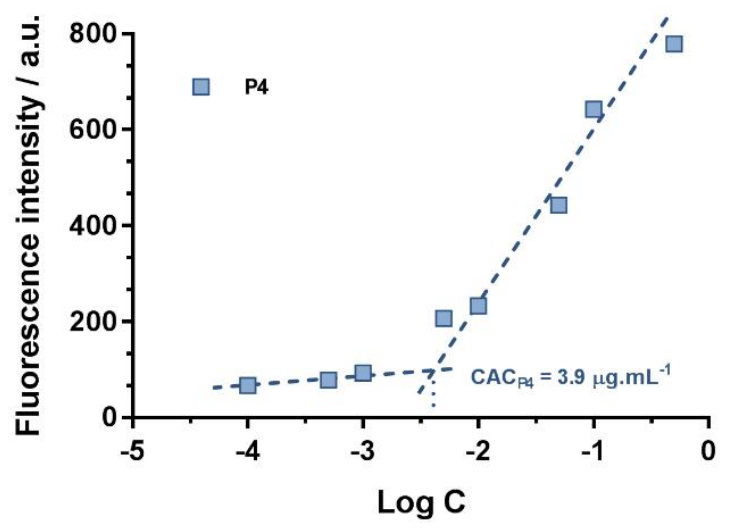

(c)

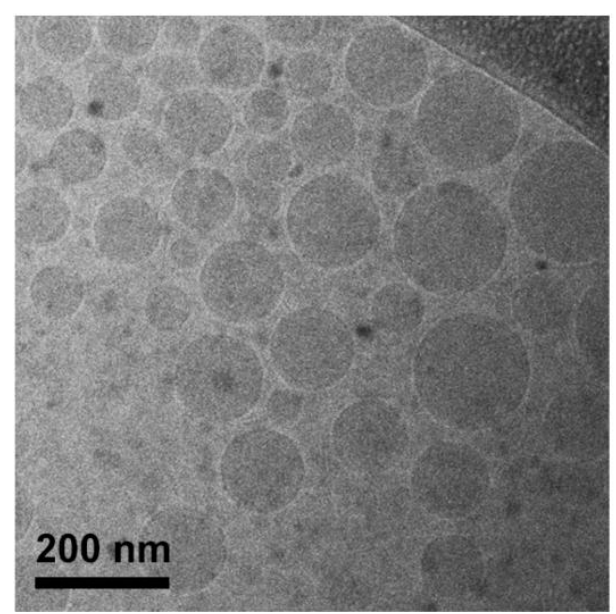

(b)

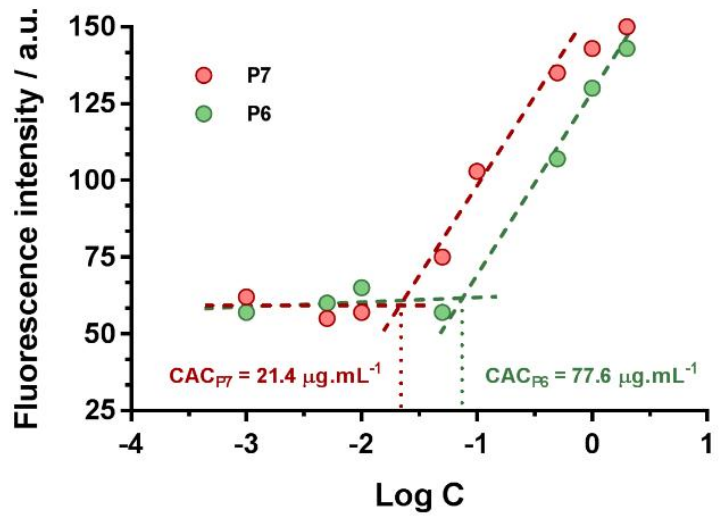

(d)

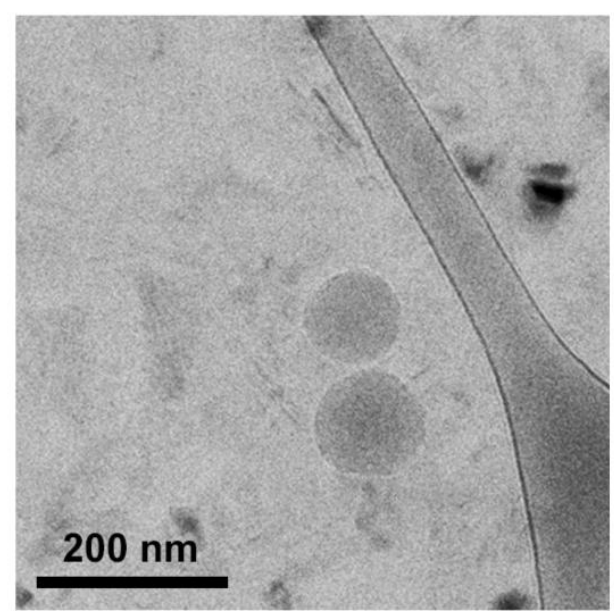

Figure 2. Measurement of the critical aggregation concentration of (a) Ptx-digly-PI P4 and (b) Ptx-digly-POEGMA P6 and P7 in water determined by fluorescence spectroscopy using coumarin 153. Representative cryogenic transmission electron microscopy (cryo-TEM) images of nanoparticles (c) $\mathbf{P 4}$ and (d) $\mathbf{P 6}$ at $5 \mathrm{mg} \cdot \mathrm{mL}^{-1}$.

The different prodrugs were then formulated into nanoparticles by the nanoprecipitation method to target a final concentration of $1 \mathrm{mg} \cdot \mathrm{mL}^{-1}$. As shown in Table 1, Ptx-digly-PI nanoparticles were formed with average diameters in the 111-236 nm range and narrow particle size distributions (PSD 0.1). Interestingly, the average diameter of Ptx-digly-PI nanoparticles gradually decreased from 236 to $111 \mathrm{~nm}$ with an increase of the PI chain length. This trend may be assigned to a higher compaction of the longer polymer chains due to increased hydrophobic interactions/lower solubility. Ptx-digly-POEGMA nanoparticles also 
displayed average diameters $(133-151 \mathrm{~nm})$ in the suitable window for drug delivery purposes together with narrow particle size distributions (Table 1). Representative cryogenic transmission electron microscopy (Cryo-TEM) images of both types of nanoparticles showed spherical morphologies and colloidal characteristics that were in good agreement with DLS data (Figure 2c, 2d and Table S1). For instance, for nanoparticles P4, the number-average diameter $\left(D_{\mathrm{n}}\right)$ determined from cryo-TEM images was equal to $141 \mathrm{~nm}$ whereas from DLS, a z-average diameter $\left(D_{\mathrm{z}}\right)$ of $133 \mathrm{~nm}$ was obtained. Interestingly, for nanoparticles $\mathbf{P 6}, D_{\mathrm{n}}$ was significantly smaller than $D_{\mathrm{z}}$ (92 vs. $133 \mathrm{~nm}$, respectively), which is likely related to the overestimated hydrodynamic volume determined by DLS because of surface POEGMA chains. To the best of our knowledge, efficient colloidal stability of all-hydrophobic Ptxinitiated polymer prodrug nanoparticles is still an unmet challenge. Indeed, it was shown that Ptx-PLA nanoparticles (the only example of such a system reported so far) led to immediate aggregation (i.e., within minutes) after addition of $\mathrm{PBS},{ }^{32}$ presumably because of salt-induced screening of the repulsive forces ${ }^{50}$ Herein, the Ptx-digly-PI nanoparticles exhibited excellent colloidal stability in water (Figure 3a and 3b), cell culture medium (Figure 3a and 3b) and PBS (Figure S7), with very little variation of the average diameter and the particle size distribution from a few weeks to nearly 3 months. Such high colloidal stability is key as the integrity of the nanoparticles will be maintained in biological fluids post-administration. This unique feature is likely the result of the strong hydrophobic interactions between PI chains together with the efficient electrostatic stabilization provided by the strongly negative surface charges, ranging from -61 to $-77 \mathrm{mV}$, as shown by zeta potential measurements (Table 1 ). The colloidal stability of Ptx-digly-POEGMA nanoparticles was also assessed in water as shown in Figure S8. 
(a)

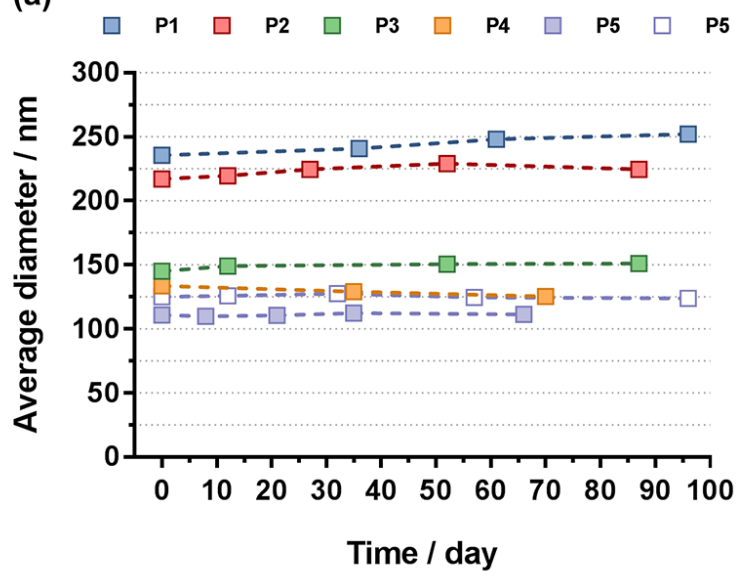

(b)

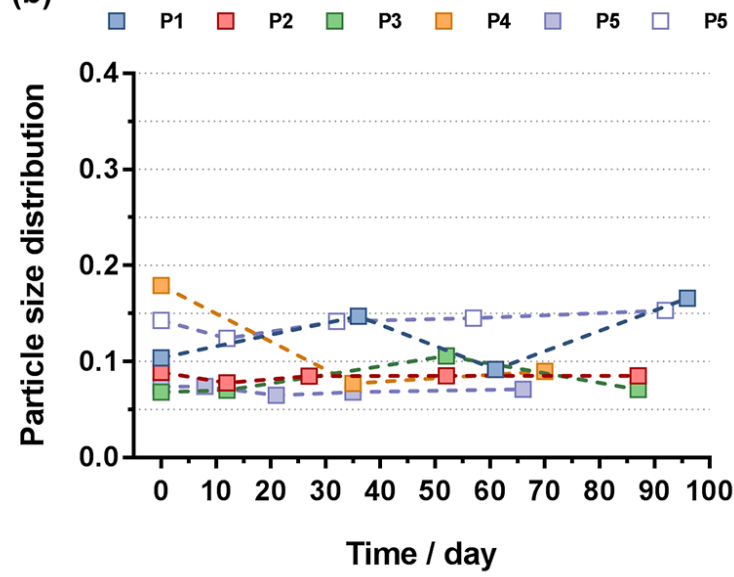

Figure 3. Evolution with time of (a) the average diameter and (b) the particle size distribution of Ptx-digly-PI nanoparticles P1-P5 in water (plain symbols) and in cell culture medium (open symbols) determined by DLS.

In addition, the average diameter of Ptx-digly-PI nanoparticles can also be tuned by varying the nanoparticle concentration during nanoprecipitation process: the higher the concentration, the higher the average diameter. For instance, when the polymer concentration was varied from 0.5 to $2.5 \mathrm{mg} \cdot \mathrm{mL}^{-1}$ at a fixed THF/water volume ratio, a gradual increase of the average diameter from $104 \mathrm{~nm}$ to $177 \mathrm{~nm}$ was observed (Figure S9).

\section{Drug release in different media}

The release of Ptx from Ptx-digly-PI and Ptx-digly-POEGMA nanoparticles was monitored by HPLC in different media (PBS and human serum) to probe the influence of the nature of the polymer and of the incubation medium over the Ptx release kinetics (Figure 4). Whereas incubation of Ptx-digly-PI nanoparticles in PBS gave nearly no Ptx release $(<0.3 \%$ after $24 \mathrm{~h})$ whatever the $M_{\mathrm{n}}$ tested, a moderate release of Ptx ( 3-5\% after $\left.24 \mathrm{~h}\right)$ was however observed in human serum under identical experimental conditions (Figure 4a). Although these results confirmed the susceptibility of the diglycolate linker to be more prone to cleavage in a 
biological medium, the amount of released Ptx is significantly lower than analogous prodrugs bearing hydrophilic drugs such as cladribine. ${ }^{36,38}$ The strongly hydrophobic environment induced by both Ptx and PI nearby the drug-polymer linkage is likely to strongly prevent its rapid cleavage, thus resulting in slow Ptx release.

(a)

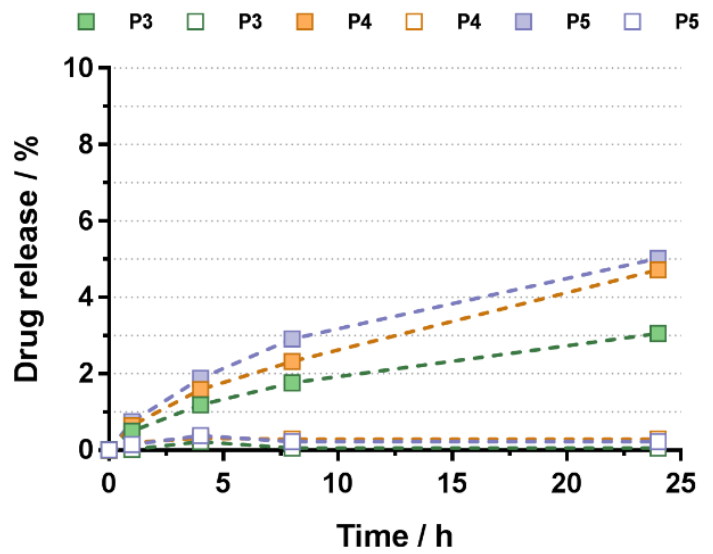

(b)

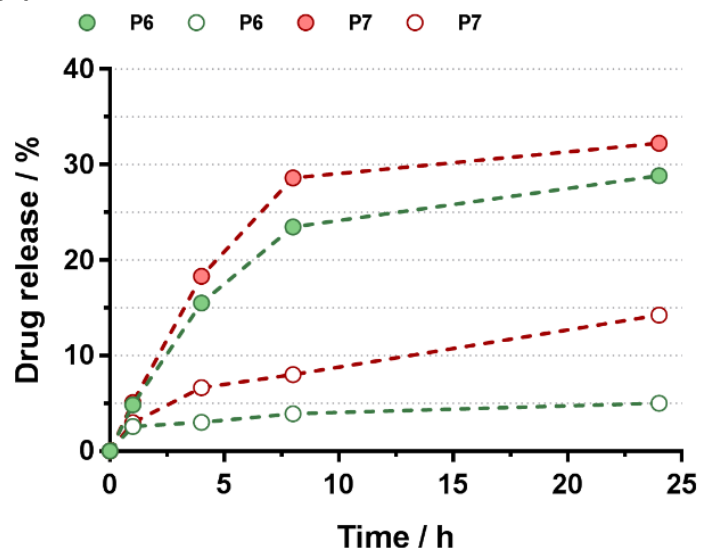

Figure 4. Ptx release profiles at $37{ }^{\circ} \mathrm{C}$ from (a) Ptx-digly-PI (P3-P5) nanoparticles and (b) Ptx-digly-POEGMA nanoparticles (P6, P7) in human serum (plain symbols) and in PBS (open symbols) determined by HPLC.

Conversely, Ptx-digly-POEGMA nanoparticles P6 and P7 exhibited significant Ptx release in human serum, reaching $\sim 30 \%$ of the total Ptx content after $24 \mathrm{~h}$ incubation (note that $\sim 25 \%$ Ptx release was already observed in less than $10 \mathrm{~h}$ ). The water-solubility of POEGMA likely counterbalanced the strong hydrophobicity of Ptx, which promoted enzymatic cleavage of the diglycolate linker. Interestingly, incubation of nanoparticles P6 and P7 in PBS led to 5\% and $14 \%$ drug release, respectively. Conversely to Ptx-digly-PI nanoparticles, these results tend to show that hydrolytic cleavage of the diglycolate linker from Ptx-digly-POEGMA nanoparticles does occur in PBS, providing a sufficient hydrophilic environment in the vicinity of the drug-polymer linkage. 


\section{Evaluation of the biological performances}

To show the versatility and the robustness of the two different systems, the in vitro cytotoxicity of Ptx-digly-PI and Ptx-digly-POEGMA nanoparticles was then investigated by cell viability assay (MTT) on three different cancer cell lines: murine leukemia (L1210), human lung carcinoma (A549) and breast adenocarcinoma (MCF-7). Ptx-digly-PI nanoparticles (P1-P5) led to significant cytotoxicity to L1210 cells whereas control AMAdigly-PI nanoparticles were not cytotoxic (Figure 5a). Interestingly, the $\mathrm{IC}_{50}$ of P1-P5 nanoparticles gradually decreased from 635 to $90 \mathrm{nM}$ (Figure 5b) with the increase of the PI chain length $\left(M_{\mathrm{n}}=2610-4310 \mathrm{~g} \cdot \mathrm{mol}^{-1}\right)$, and approached the $\mathrm{IC}_{50}$ of free Ptx $\left(\mathrm{IC}_{50}=20 \mathrm{nM}\right)$. This $M_{\mathrm{n}}$ vs. $\mathrm{IC}_{50}$ trend is likely assigned to two parameters which may strongly influence the cellular uptake of the nanoparticles by cancer cells and eventually the cytotoxicity: (i) the nanoparticle size, that is smaller for higher $M_{\mathrm{n}}$ and/or (ii) a change in the composition of the nanoparticle corona, that is known to play a pivotal role in the nanoparticle fate ${ }^{51}$ (herein, a more hydrophobic surface is expected for a higher $\left.M_{\mathrm{n}}\right)$. On A549 cells, Ptx-digly-PI (P3-P5) nanoparticles gave very similar cytotoxicity profiles, with even greater cytotoxicity, whereas Ptx-free AMA-digly-PI nanoparticles were still not cytotoxic (Figure 5c). Here again, gradually increasing the $M_{\mathrm{n}}$ of Ptx-digly-PI from 2790 to 4310 g.mol ${ }^{-1}$ enabled a decrease in the $\mathrm{IC}_{50}$ of the corresponding nanoparticles from 132 to $8 \mathrm{nM}$ (Figure 5d), thus reaching the same $\mathrm{IC}_{50}$ as free $\mathrm{Ptx}(6 \mathrm{nM})$. 
(a)

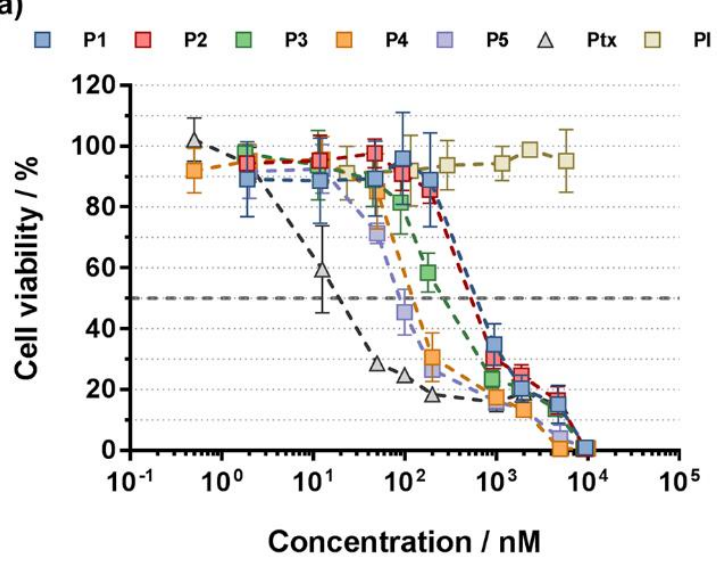

(c) $\quad \square \quad \mathrm{P3} \quad \square \quad \mathrm{P} 4 \quad \square \quad \mathrm{P5} \quad \triangle \quad \mathrm{Ptx} \quad \square \quad \mathrm{PI}$

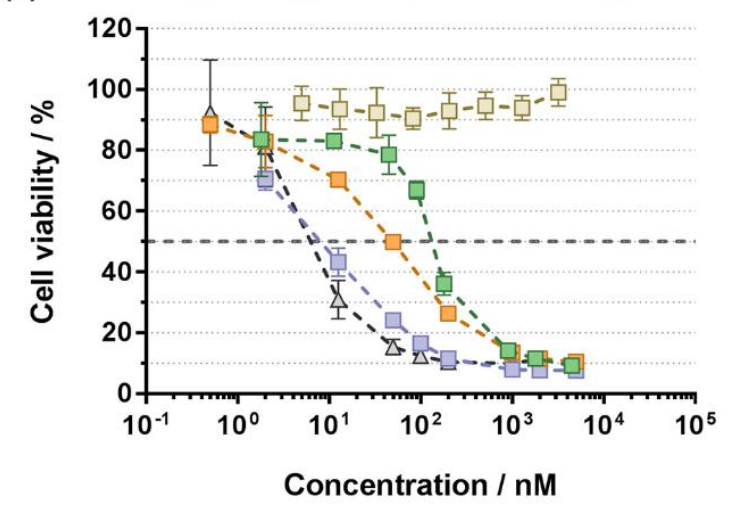

(b)

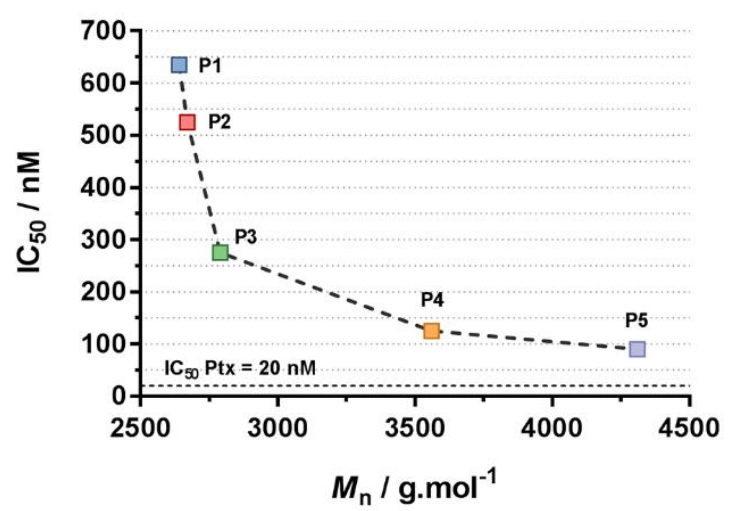

(d)

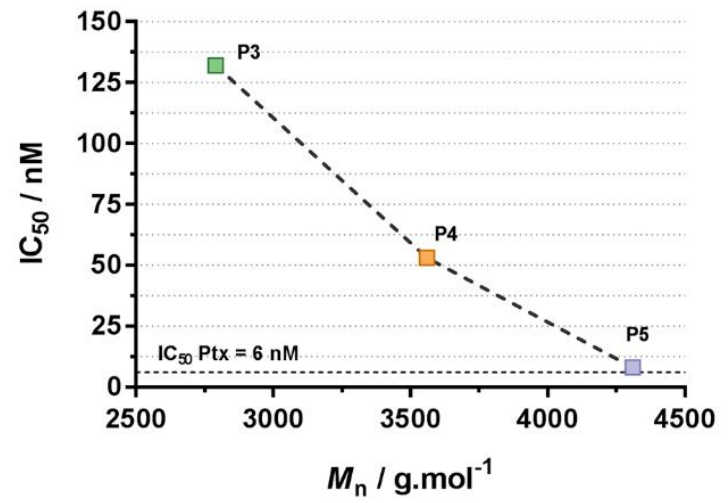

Figure 5. Cytotoxicity assay on (a) L1210 cells and (c) A549 cells with increasing concentrations of Ptx-digly-PI nanoparticles P1-P5, AMA-digly-PI and free Ptx after an incubation period of $72 \mathrm{~h}$. The horizontal dashed line indicates the $\mathrm{IC}_{50}$. Evolution of the $\mathrm{IC}_{50}$ of Ptx-digly-PI nanoparticles P1-P5 as function of the $M_{\mathrm{n}}$ after cytotoxicity assay on (b) L1210 cells and (d) A549 cells. The horizontal dashed line indicates the $\mathrm{IC}_{50}$.

Switching from fully hydrophobic Ptx-digly-PI nanoparticles to PEGylated Ptx-diglyPOEGMA nanoparticles also resulted in strong cytotoxicity on both L1210 and A549 cell lines (Figur 6). Importantly, the $\mathrm{IC}_{50}$ values were very close, if not lower, than that of free Ptx, thus indicating high anticancer activity. On L1210 cells, the $\mathrm{IC}_{50}$ of Ptx-digly-POEGMA P6P7 nanoparticles was equal to $30 \mathrm{nM}\left(\mathrm{IC}_{50} \mathrm{Ptx}=20 \mathrm{nM}\right)$, whereas on A549 cells it was in the 4-9 $\mathrm{nM}$ range $\left(\mathrm{IC}_{50} \mathrm{Ptx}=6 \mathrm{nM}\right)$. These remarkable results can be correlated with the greater Ptx release profiles in human serum of Ptx-digly-POEGMA nanoparticles compared to those 
of Ptx-digly-PI nanoparticles (Figure 4). Conversely to Ptx-digly-PI nanoparticles, no apparent chain-length dependency was however observed with Ptx-digly-POEGMA nanoparticles. This observation may be correlated to a marginal difference in terms of average diameter for the two Ptx-digly-POEGMA conjugates used (Table 1).

(a)

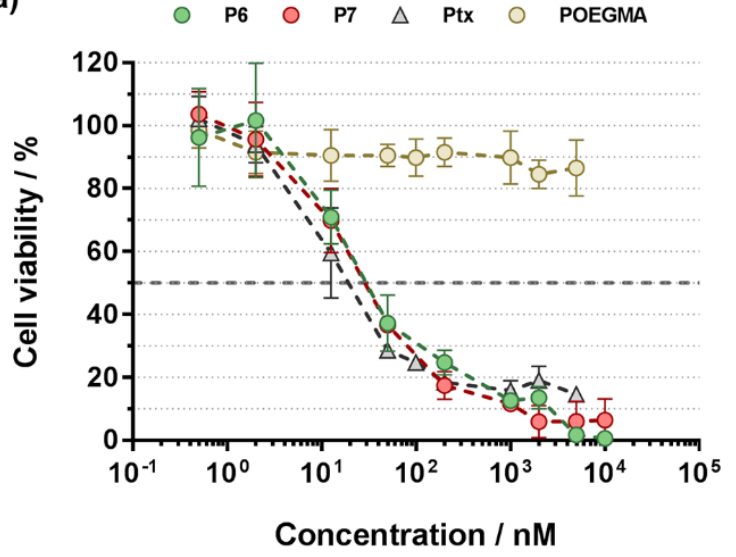

(b)

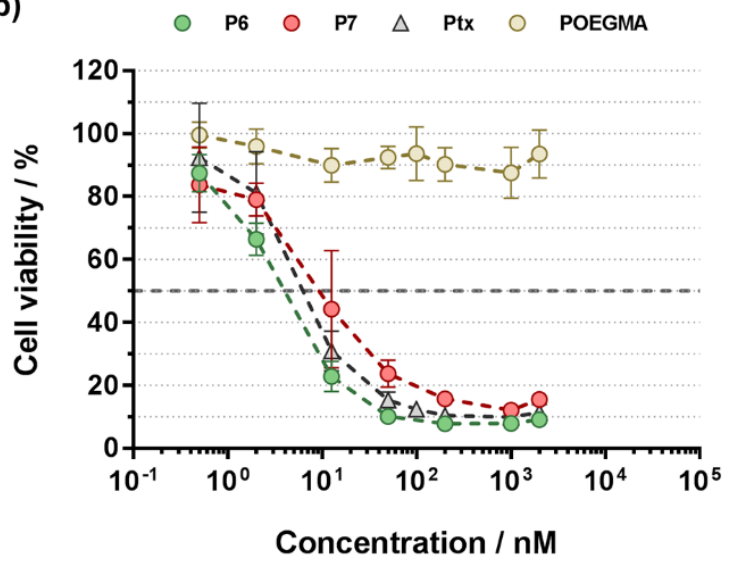

Figure 6. Cytotoxicity assay on (a) L1210 cells or (b) A549 cells with increasing concentrations of Ptx-digly-POEGMA nanoparticles P6-P7, AMA-digly-POEGMA and free Ptx after an incubation period of $72 \mathrm{~h}$. The horizontal dashed line indicates the $\mathrm{IC}_{50}$.

The most cytotoxic Ptx-based polymer prodrug nanoparticles from each series (i.e., Ptx-diglyPI P5 and Ptx-digly-POEGMA P6) were then tested for their cytotoxicity on MCF-7 as a third cancer cell line to demonstrate the broad efficacy of our materials. They both led to high cytotoxicity with $\mathrm{IC}_{50}$ value of $27 \mathrm{nM}$ and $8 \mathrm{nM}$, respectively (Figure $\mathrm{S} 10$ ), whereas the $\mathrm{IC}_{50}$ of free Ptx on this cell line was equal to $25 \mathrm{nM}^{52}$

\section{Internalization into cancer cells}

To give insight on the uptake mechanism, the in vitro fate of Ptx-digly-PI P5 and Ptx-diglyPOEGMA P6 nanoparticles was then investigated in A549 cells by means of confocal microscopy. To accurately study the subcellular localization of the nanoparticles, they were 
prepared by co-nanoprecipitation of the desired prodrug with a small amount of a similarlyconstructed fluorescent naphthalimide-polyisoprene (Napht-PI, $M_{\mathrm{n}}=3700$ g.mol ${ }^{-1}, Ð=1.20$, 1 wt.\% dye content) exhibiting aggregation-induced emission (AIE) properties. ${ }^{37,53}$ Conversely to the traditional encapsulation of a free hydrophobic dye, this approach rules out potential leakage of the dye from the nanoparticles (leading to confocal image misinterpretation),${ }^{54}$ enables sharp fluorescence signal and accurate subcellular localization.

A549 cells were incubated for $24 \mathrm{~h}$ with the fluorescently-labeled prodrug nanoparticles P5 and P6, after staining of lysosomes and nuclei by LysoTracker Red and Hoechst 33342, respectively. As shown in Figures 7 and 8, a bright green fluorescence signal from P5 or P6 (green channel, 450-560 nm, $\lambda_{\mathrm{ex}}=405 \mathrm{~nm}$ ) was observed in A549 cells demonstrating their efficient internalization. By overlaying this channel with the red $\left(569-682 \mathrm{~nm}, \lambda_{\mathrm{ex}}=543 \mathrm{~nm}\right)$ and blue $\left(410-440 \mathrm{~nm}, \lambda_{\mathrm{ex}}=405 \mathrm{~nm}\right)$ channels, an intense yellow/orange colocalization signal was observed in both cases. These results demonstrated that Ptx-digly-PI and Ptx-digly-POEGMA nanoparticles were located in the lysosomes and strongly supported an internalization mechanism by endocytosis. 

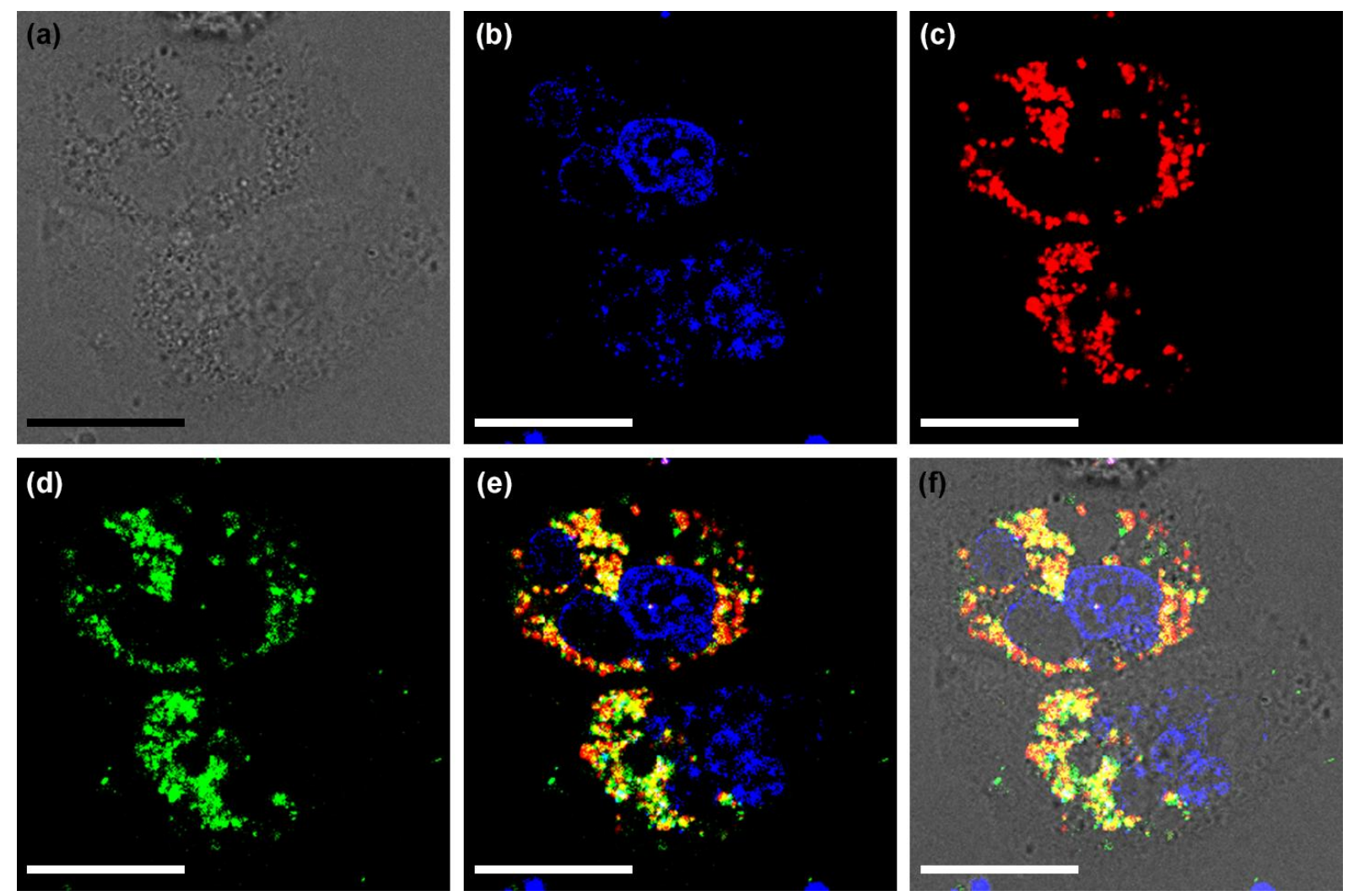

Figure 7. (a) Nomarski image of A549 cells; (b-d) confocal microscopy images [(b) blue (Hoechst 33342), (c) red (LysoTracker Red) and (d) green (Napht)]; (e) merge of confocal microscopy images (b-d) and (f) merge of Nomarski image with confocal microscopy images (b-d), after a 24 h incubation of A549 cells with Ptx-digly-PI P5 nanoparticles. Scale bar = 20 $\mu \mathrm{m}$. 

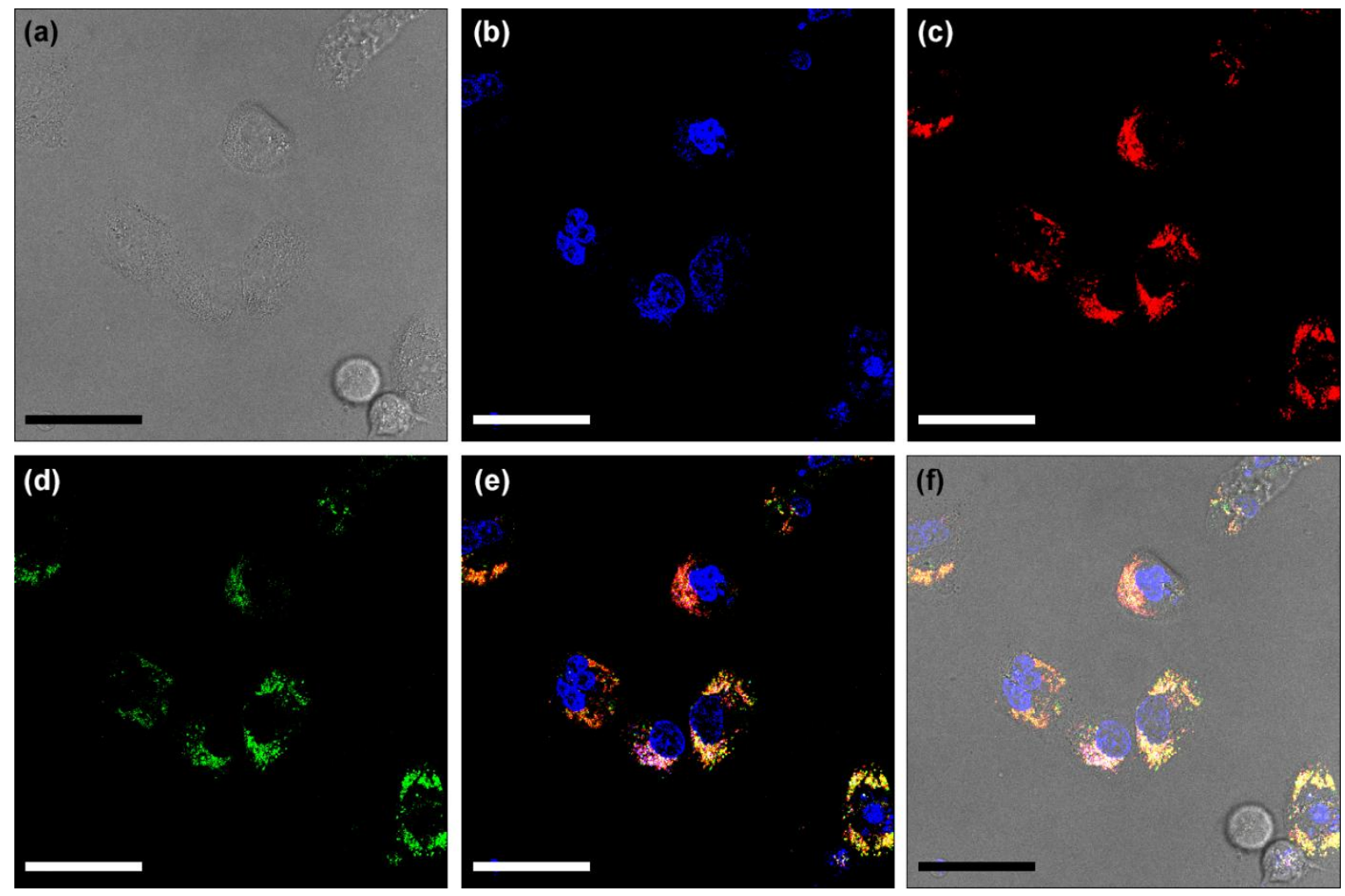

Figure 8. (a) Nomarski image of A549 cells; (b-d) confocal microscopy images [(b) blue (Hoechst 33342), (c) red (LysoTracker Red) and (d) green (Napht)]; (e) merge of confocal microscopy images (b-d) and (f) merge of Nomarski image with confocal microscopy images (b-d), after a 24 h incubation of A549 cells with Ptx-digly-POEGMA P6 nanoparticles. Scale bar $=50 \mu \mathrm{m}$.

\section{Conclusion}

The versatile derivatization of Ptx was achieved by means of the drug-initiated method and illustrated by the synthesis of various well-defined Ptx-based polymer prodrugs with high drug loadings from two different RDRP techniques. It enabled, for the first time, the formation of either self-stabilized, all-hydrophobic Ptx-polymer prodrug nanoparticles or their PEGylated counterparts, thus conferring great flexibility in regard the development of nanocarriers for drug delivery. Remarkably, their biological evaluations gave high cytotoxicity on three different cancer cell lines, with chain length-cytotoxicity dependency 
and $\mathrm{IC}_{50}$ values comparable to those of the parent drug. This work not only further demonstrates the robustness and the broad use of the drug-initiated method for the simple design of efficient polymer prodrug nanoparticles, but it also opens new perspectives in the field of nanomedicine as it shows that polymers of opposite nature (i.e., hydrophobic and water-soluble) can successfully be grown from Ptx, leading in both cases to efficient anticancer nanoparticles with very different surfaces properties.

\section{Acknowledgment}

This work is supported by a Marie Curie Intra-European Fellowship (YB) from European Commission (No. 623501) and the French Ministry of Research for the financial support of the PhD thesis of EG. The authors thank Didier Desmaële (Institut Galien Paris-Sud) for fruitful discussions, Valérie Nicolas (Institut Paris-Sud d'Innovation Therapeutique (IPSIT), Université Paris-Sud) for technical assistance in confocal imaging, Stéphanie Denis (Institut Galien Paris-Sud) for technical assistance in cell culture and Stéphanie Nicolaÿ for mass spectrometry analyses (Service d'Analyses des Médicaments et Métabolites, IPSIT, IFR 141, Université Paris-Sud). CNRS and University Paris-Sud are also acknowledged for financial support.

\section{Reference}

1. M. C. Wani, H. L. Taylor, M. E. Wall, P. Coggon and A. T. McPhail, J. Am. Chem. Soc., 1971, 93, 2325-2327.

2. W. P. McGuire, E. K. Rowinsky, N. B. Rosenshein and et al., Ann. Intern. Med., 1989, 111, 273-279.

3. F. A. Holmes, R. S. Walters, R. L. Theriault, A. U. Buzdar, D. K. Frye, G. N. Hortobagyi, A. D. Forman, L. K. Newton and M. N. Raber, JNCI: Journal of the National Cancer Institute, 1991, 83, 1797-1805.

4. E. K. Rowinsky and R. C. Donehower N. Engl. J. Med., 1995, 332, 1004-1014. 
5. R. T. Liggins, W. L. Hunter and H. M. Burt, J. Pharm. Sci., 1997, 86, 1458-1463.

6. A. Sparreboom, O. van Tellingen, W. J. Nooijen and J. H. Beijnen, Cancer Res., 1996, 56, 2112-2115.

7. J. Szebeni, C. R. Alving and F. M. Muggia, J. Natl. Cancer Inst., 1998, 90, 300-306.

8. P. H. Wiernik, E. L. Schwartz, J. J. Strauman, J. P. Dutcher, R. B. Lipton and E. Paietta, Cancer Res., 1987, 47, 2486-2493.

9. R. B. Weiss, R. C. Donehower, P. H. Wiernik, T. Ohnuma, R. J. Gralla, D. L. Trump, J. R. B. Jr, D. A. V. Echo, D. D. V. Hoff and B. Leyland-Jones, J. Clin. Oncol., 1990, 8, 1263-1268.

10. D. A. Boyle and B. R. Goldspiel, Clin. J. Oncol. Nurs., 1998, 2, 141-145.

11. B. Louage, O. De Wever, W. E. Hennink and B. G. De Geest, J. Control. Rel., 2017, 253, 137-152.

12. W. J. Gradishar, Exp. Opin. Pharmacother., 2006, 7, 1041-1053.

13. T.-Y. Kim, D.-W. Kim, J.-Y. Chung, S. G. Shin, S.-C. Kim, D. S. Heo, N. K. Kim and Y.-J. Bang, Clin. Cancer Res., 2004, 10, 3708-3716.

14. K. Kato, K. Chin, T. Yoshikawa, K. Yamaguchi, Y. Tsuji, T. Esaki, K. Sakai, M. Kimura, T. Hamaguchi, Y. Shimada, Y. Matsumura and R. Ikeda, Invest. New Drugs, 2012, 30, 1621-1627.

15. J. S. Sohn, J. I. Jin, M. Hess and B. W. Jo, Polym. Chem., 2010, 1, 778-792.

16. V. Delplace, P. Couvreur and J. Nicolas, Polym. Chem., 2014, 5, 1529-1544.

17. S. Knutson, E. Raja, R. Bomgarden, M. Nlend, A. Chen, R. Kalyanasundaram and S. Desai, PLoS One, 2016, 11, e0157762.

18. C. Li, S. Ke, Q.-P. Wu, W. Tansey, N. Hunter, L. M. Buchmiller, L. Milas, C. Charnsangavej and S. Wallace, Clin. Cancer Res., 2000, 6, 2829-2834.

19. X. Zhang, Y. Li, X. Chen, X. Wang, X. Xu, Q. Liang, J. Hu and X. Jing, Biomaterials, 2005, 26, 2121-2128.

20. Y. Yu, C.-K. Chen, W.-C. Law, J. Mok, J. Zou, P. N. Prasad and C. Cheng, Mol. Pharm., 2013, 10, 867-874.

21. I. J. Majoros, A. Myc, T. Thomas, C. B. Mehta and J. R. Baker, Biomacromolecules, 2006, 7, 572-579.

22. Y. Zhong, K. Goltsche, L. Cheng, F. Xie, F. Meng, C. Deng, Z. Zhong and R. Haag, Biomaterials, 2016, 84, 250-261.

23. S. Zhang, J. Zou, M. Elsabahy, A. Karwa, A. Li, D. A. Moore, R. B. Dorshow and K. L. Wooley, Chem. Sci., 2013, 4, 2122-2126.

24. A. W. Du, H. Lu and M. H. Stenzel, Biomacromolecules, 2015, 16, 1470-1479.

25. S. Lv, Z. Tang, D. Zhang, W. Song, M. Li, J. Lin, H. Liu and X. Chen, J. Control. Rel., 2014, 194, 220-227.

26. J. Zou, G. Jafr, E. Themistou, Y. Yap, Z. A. P. Wintrob, P. Alexandridis, A. C. Ceacareanu and C. Cheng, Chem. Commun., 2011, 47, 4493-4495.

27. J. Zou, Y. Yu, Y. Li, W. Ji, C.-K. Chen, W.-C. Law, P. N. Prasad and C. Cheng, Biomaterials Science, 2015, 3, 1078-1084.

28. J. Nicolas, Chem. Mater., 2016, 28, 1591-1606.

29. R. Tong and J. Cheng, J. Am. Chem. Soc., 2009, 131, 4744-4754.

30. R. Tong and J. Cheng, Bioconjugate Chem., 2009, 21, 111-121.

31. R. Tong and J. Cheng, Macromolecules, 2012, 45, 2225-2232.

32. R. Tong and J. Cheng, Angew. Chem., Int. Ed., 2008, 47, 4830-4834.

33. D. T. Bui, A. Maksimenko, D. Desmaele, S. Harrisson, C. Vauthier, P. Couvreur and J. Nicolas, Biomacromolecules, 2013, 14, 2837-2847.

34. A. Maksimenko, D. T. Bui, D. Desmaële, P. Couvreur and J. Nicolas, Chem. Mater., 2014, 26, 3606-3609. 
35. S. Harrisson, J. Nicolas, A. Maksimenko, D. T. Bui, J. Mougin and P. Couvreur, Angew. Chem., Int. Ed., 2013, 52, 1678-1682.

36. Y. Bao, T. Boissenot, E. Guégain, D. Desmaële, S. Mura, P. Couvreur and J. Nicolas, Chem. Mater., 2016, 28, 6266-6275.

37. Y. Bao, V. Nicolas and J. Nicolas, Chem. Commun., 2017, 53, 4489-4492.

38. Y. Bao and J. Nicolas, Polym. Chem., 2017.

39. B. Louage, L. Nuhn, M. D. P. Risseeuw, N. Vanparijs, R. De Coen, I. Karalic, S. Van Calenbergh and B. G. De Geest, Angew. Chem., Int. Ed., 2016, 55, 11791-11796.

40. B. Louage, M. J. van Steenbergen, L. Nuhn, M. D. P. Risseeuw, I. Karalic, J. Winne, S. Van Calenbergh, W. E. Hennink and B. G. De Geest, ACS Macro Letters, 2017, 6, $272-$ 276.

41. H. Maeda, J. Control. Rel., 2012, 164, 138-144.

42. G. Storm, S. O. Belliot, T. Daemen and D. D. Lasic, Adv. Drug Delivery Rev., 1995, 17, 31-48.

43. S. Harrisson, P. Couvreur and J. Nicolas, Polym. Chem., 2011, 2, 1859-1865.

44. S. Harrisson, P. Couvreur and J. Nicolas, Macromolecules, 2011, 44, 9230-9238.

45. T. J. V. Prazeres, M. Beija, F. V. Fernandes, P. G. A. Marcelino, J. P. S. Farinha and J. M. G. Martinho, Inorg. Chim. Acta, 2012, 381, 181-187.

46. D. G. I. Kingston, Chem. Commun., 2001, 867-880.

47. T. Watanabe, S. Sato, Y. Honda and M. Kuwahara, Biomacromolecules, 2003, 4, 321329.

48. , US 4596728, 1986.

49. J.-F. Lutz, J. Polym. Sci., Part A: Polym. Chem., 2008, 46, 3459-3470.

50. A.-L. Kjøniksen, F. Joabsson, K. Thuresson and B. Nyström, J. Phys. Chem. B, 1999, 103, 9818-9825.

51. M. P. Monopoli, C. Aberg, A. Salvati and K. A. Dawson, Nat. Nanotechnol., 2012, 7, 779-786.

52. S. Mura, F. Zouhiri, S. Lerondel, A. Maksimenko, J. Mougin, C. Gueutin, D. Brambilla, J. Caron, E. Sliwinski, A. LePape, D. Desmaele and P. Couvreur, Bioconjugate Chem., 2013.

53. Y. Bao, H. De Keersmaecker, S. Corneillie, F. Yu, H. Mizuno, G. Zhang, J. Hofkens, B. Mendrek, A. Kowalczuk and M. Smet, Chem. Mater., 2015, 27, 3450-3455.

54. P. Xu, E. Gullotti, L. Tong, C. B. Highley, D. R. Errabelli, T. Hasan, J.-X. Cheng, D. S. Kohane and Y. Yeo, Mol. Pharm., 2009, 6, 190-201. 